\title{
Directions for InstillingEconomic and Environmental Sustainability across Product Supply Chains
}

\author{
Gül E. Kremer, Professor \\ School of Engineering Design and Department of Industrial \& Manufacturing Engineering \\ Penn State University \\ 213T Hammond Building, University Park, PA 16802, USA \\ gkremer@psu.edu \\ Karl Haapala, Assistant Professor \\ School of Mechanical, Industrial, and Manufacturing Engineering \\ Oregon State University \\ 204 Rogers Hall, Corvallis, OR 97331 \\ karl.haapala@oregonstate.edu \\ Alper Murat, Associate Professor \\ Ratna Babu Chinnam*, Professor \\ Kyoung-yun Kim, Associate Professor \\ Leslie Monplaisir, Associate Professor \\ Industrial \& Systems Engineering Department \\ Wayne State University \\ 4815 Fourth Street, Detroit, MI 48202, USA \\ amurat ratna.chinnam kykim leslie.monplaisir@wayne.edu \\ Ting Lei, Graduate Student \\ Department of Industrial \& Manufacturing Engineering \\ Penn State University \\ 301C Engineering Units, University Park, PA 16802, USA \\ tingleipsu@gmail.com
}

\begin{abstract}
Although sustainability is a frequent topicin product development literature, the often segmented and narrow scopeof prior workslimits the potential benefits of theindustrial application ofmethods, models, and tools developed by the research community. The workherein has the goal of coalescing relevant, recent work supporting the economic and environmental aspects of sustainability for early stage product development by focusing on the interfaces between product design and supply chain operations. This discussion is intendedto highlight past accomplishments and to be a call for action to the research community for the development of integrated methods, models, and toolsto support sustainability initiatives across product supply chains.A literature review spanning product design, manufacturing, and supply operations management reveals severalnear-term research needs, which are organizedinto four highly promising foci addressing product architecture engineering, assembly/disassembly operation modeling, manufacturing process modeling, and joint optimization of life cycle activities. Finally, potential avenues for future collaborative research are presented and discussed.

\section{Key Words}

Sustainability, Product Design, DfX, Manufacturing, Remanufacturing, Supply Chain, Optimization.

${ }^{*}$ Corresponding Author: Tel.: 313-577-4846; Fax: 313-578-5902.
\end{abstract}




\section{Introduction}

Consumers are demanding more environmentally sustainable products, motivated by increased awareness of environmental impacts. Simultaneously, environmental regulations, policies, and standards have been enacted globally that impact manufacturers(Gutowski et al. 2005). Yet, product manufacturers continue to struggle with how to set, assess, and achieve sustainability goals, which encompass economic, environmental, and social factors. To meet this challenge, the research community has developed many approaches, several of which are highlighted in the sections below and many others which have been reviewed by other authors at length(e.g., Baumann, Boons, and Bragd 2002; Duflou et al. 2012; Gold, Seuring, and Beske 2010; Haapala et al. 2013; Ilgin and Gupta 2010; Ramani et al. 2010; Sarkis, Zhu, and Lai 2011; Seuring and Müller 2008; Subramanian, Talbot, and Gupta 2010; Umeda et al. 2012)in the areas of product design, product manufacturing and assembly, demanufacturing and remanufacturing, and supply chain management. Seuring and Müller (2008)synthesized an extensive literature review of 191 scholarly articles on sustainable supply chain management published during 19942007. They found that studies primarily focus on environmental issues and on empirical findings, and this fact has limited the development of a theoretical basis for supply chain management. Given this situation, in this paper, we review the sustainability literature with a specific focus on product design and supply chain operations, and then provide an action plan to improve the analysis and reduction of cost and environmental impacts in supply chains.

The goal of this paper is two-fold: first, to review and present recent research undertaken to advance environmentally and economically sustainable product development from the earliest stages of design through manufacturing and end-of-life (EOL) and, second, to define and discuss several near-term research foci that can be addressed by the product design and manufacturing research community. Thus, the bulk of the discussion focuses on the fields of product design, manufacturing and assembly, and supply chain management activities. Accordingly, the novelty and contributions of this paper are two-fold. First, it provides a unified review of past work on sustainability across product supply chains and identifies gaps due to considering product design, manufacturing,and supply chain operationsin isolation from each other. Secondly, and in an effort to close these gaps, it develops an integrated view of decision making in product design, manufacturing, and supply chain operations, under the lens of sustainability.

While definitions vary, it is generally agreed that sustainability requires "...the design of human andindustrial systems to ensure that humankind's use of naturalresources and cycles do not lead to diminished quality of lifedue either to losses in future economic opportunities or toadverse impacts on social conditions, human health and the environment"(Mihelcic et al. 2003). A myriad of metrics have been proposed to measure progress and improvement, including those for economic, environmental, and social aspects of sustainable product development(Feng and Joung 2011; Graedel and Allenby 2002; Hutchins and Sutherland 2008; Lu et al. 2010; OECD 2008; Shuaib et al. 2011), e.g., capital, operational, and transportation cost; $\mathrm{CO}_{2}$, SOx, and NOx emissions; and worker wages, benefits, and equality.The carbon footprint of a product is often used as a measure of its environmental sustainability. While carbon footprint has limitations, it is an important recent metric and used herein to focus the discussion around a concrete concept of environmental impact when needed. Ideas discussed in the context of carbon footprint can be extended to other environmental impacts as well. Similarly, economic impacts 
are only discussed in terms of direct, product-related costs. While integral to any sustainability evaluation, social aspects are outside of the scope of the present discussion.

Product development covers the stages of concept development, product design, supply chain design, and production ramp-up and launch (Krishnan and Ulrich 2001). Design stage is iterative and complex, and includes defining, conceptualizing, refining the design to ultimately commercialize a product in the market(Ogot and Okudan-Kremer 2004). The shape, dimensions, functions, components, and materials are all decided during the design process; as a consequence of this, up to about $70 \%$ of product cost (Appelqvist et al., 2004) and $80 \%$ of product quality (Dowlatshahi 1992) are decided during the design stage. One can posit that product life cycle environmental impacts are similarly designed-in.Merging early eco-design tools with life cycle data and developing a better understanding of product and environmental interactions are key to achieving sustainable product development (Ramani et al. 2010). Baumann and colleagues(Baumann, Boons, and Bragd 2002)reviewed the green product development literature from engineering, management/business studies, and policy studies. One of the primary conclusions of this extensive review is that there isneed for a systemic perspective where environmental optimization and emissions reduction should be considered across the entire supply chain.

It is estimated that about $72 \%$ of $\mathrm{GHG}$ emissions are related to household consumption(Hertwich and Peters 2009), implying that consumer products and services, and their supply chains are the major contributor. Matthews, Hendrickson, and Weber (2008)asserted that only $26 \%$ of total supply chain emissions are identified and mitigated. Moreover, the increasing trend towards outsourcing is leading to the substantial growth of the global carbon footprint, even without accounting for associated transportation, due to less efficient energy generation and manufacturing processes in developing nations (Herrmann and Hauschild 2009). In fact, much of the success in $\mathrm{CO}_{2}$ emissions reductions in developed countries are due toexported industrial production to Asia. In 2005, about $30 \%$ of the emissions in Chinawere attributable to the production of exports (Weber and Matthews 2008). Thus, analytical methods are needed to aid in the development of products and related supply chainsand will be further reviewed in this paper.

The rest of the paper is organized as follows: Section 2 reviews prior work; Section 3 discusses four promising foci for instilling sustainability across product supply chains; Section 4 presents results from preliminary work to instill sustainability across product supply chains; finally, Section 5 suggests directions for future research and concludes.

\section{Prior Work}

A recent review by Chiu and Okudan Kremer (2011)identified 12 different tools (guideline sets, metrics, mathematical models, and methods) for Design for Environment (DfE) and DfS. It was readily evident, however, that these methods focus on environmental sustainability and are deficient in incorporating economic sustainability. Several of these works are listed in Table 1 below.

Table 1. Prior work proposing processes and models to achieve sustainable designs.

\begin{tabular}{|l|l|}
\hline $\begin{array}{l}\text { Anastas and } \\
\text { Zimmerman }\end{array}$ & $\begin{array}{l}\text { Proposed "Twelve Principles of Green Engineering" to achieve sustainable design } \\
\text { by reducing hazardous and non-hazardous waste and energy use. }\end{array}$ \\
\hline
\end{tabular}




\begin{tabular}{|l|l|}
\hline (2003) & \\
\hline Ljungberg (2007) & $\begin{array}{l}\text { Provided guidelines to minimize materials, energy, emissions, and toxic elements } \\
\text { over the life of a product, while maximizing renewable resource use, recyclable } \\
\text { materials, energy efficiency, and product life. }\end{array}$ \\
\hline $\begin{array}{l}\text { Howarth and } \\
\text { Hadfield (2006) }\end{array}$ & $\begin{array}{l}\text { Developed a two-part model for designers to review the sustainability of a product } \\
\text { in the detail design phase. }\end{array}$ \\
\hline Waage (2007) & $\begin{array}{l}\text { Presented a four phase process for achieving sustainable designs. These phases } \\
\text { comprise establishing the sustainability context, defining the sustainability issues, } \\
\text { assessing and acting, and receiving feedback. }\end{array}$ \\
\hline $\begin{array}{l}\text { Short and Lynch } \\
(2004)\end{array}$ & $\begin{array}{l}\text { Presented Design for Sustainability Matrix (DfSM), which analyzes the functional } \\
\text { and environmental profile of a product. }\end{array}$ \\
\hline $\begin{array}{l}\text { Spangenberg et } \\
\text { al. (2010) }\end{array}$ & $\begin{array}{l}\text { Provided a framework supporting the design for sustainability (DfS) idea through } \\
\text { sustainable design and consumption analysis. }\end{array}$ \\
\hline
\end{tabular}

Considerable research has been undertaken to integrate life cycle concerns into the design stage through design for X (DfX) concepts (e.g., design for manufacturing (DfM), design for assembly (DfA), and design for environment (DfE)). However, there is no research-based evidence on how various DfX tools complement or compromise one another across the supply chain (Chiu and Okudan 2011; Chiu and Okudan Kremer 2011). In addition, while other DfX principles have been studied for decades, the design for environment (DfE) and design for sustainability (DfS) methods have been developed more recently. Given that gaps exist at the interface of DFA, DFM, and design for supply chain (DfSC), the integration of these methods with DfE and DfS is absent from the prevailing literature. Filling this gap by identifying important research questions and their answers is timely and will address the needs of industrial decision makers. Since they inherently take a holistic view, DfE and DfS methods interface with all other DfX approaches, which differentiates them from other DfX considerations (e.g., DfM is only concerned with the manufacturing stage). We assert that manufacturers must remain cost competitive, and design for sustainability is not complete without simultaneous consideration of environmental and economic aspects (e.g., carbon footprint and costs) of manufacturing and assembly activities across the supply chain.Several studies have been done to integrate economic sustainability into design and into manufacturing processing; these are summarized in the following table.

Table 2. Prior work integrating economic sustainability into design.

\begin{tabular}{|l|l|}
\hline Ijomah et al. (2007) & $\begin{array}{l}\text { Incorporated process aspects and provided Design for Remanufacturing (DfRem) } \\
\text { guidelines. }\end{array}$ \\
\hline Pham et al. (2008) & $\begin{array}{l}\text { Combined lean, agility, and sustainability factors to form a framework for "Fit" } \\
\text { manufacturing to improve the current state to meet sustainability and other } \\
\text { business performance requirements. }\end{array}$ \\
\hline Choi et al. (2008) & $\begin{array}{l}\text { Introduced a framework including both environmental and business aspects of } \\
\text { product design to help decision makers. }\end{array}$ \\
\hline Ferrer et al. (2009) & $\begin{array}{l}\text { DfM guidelines and manufacturing process information were integrated to make } \\
\text { design decisions more conveniently. }\end{array}$ \\
\hline Kwak et al. (2009) & $\begin{array}{l}\text { Proposed eco-architectureanalysis for product end-of-life (EOL) considerations } \\
\text { during design andfor identifying recycling opportunities. }\end{array}$ \\
\hline Komoto et al. (2009) & $\begin{array}{l}\text { Used life cycle simulation (LCS) to investigate the product supply chain and } \\
\text { end-of-life when stochastic data are applied. }\end{array}$ \\
\hline $\begin{array}{l}\text { Vinodh and Rathod } \\
\text { (2010) }\end{array}$ & \begin{tabular}{l} 
Incorporated sustainability to product design and life cycle assessment (LCA). \\
\hline
\end{tabular}
\end{tabular}




\begin{tabular}{|l|l|}
\hline $\begin{array}{l}\text { Spangenberg et al. } \\
(2010)\end{array}$ & $\begin{array}{l}\text { Developed framework to support design for sustainability (DfS) idea by working } \\
\text { on sustainable design and consumption analysis. }\end{array}$ \\
\hline $\begin{array}{l}\text { Devanathan et al. } \\
(2010)\end{array}$ & Developed an eco-design tool focusing on the early design process. \\
\hline $\begin{array}{l}\text { Chiu and Okudan } \\
(2011)\end{array}$ & $\begin{array}{l}\text { Presented an approach that considers supply chain cost and carbon footprint } \\
\text { analyses early in the design stage. }\end{array}$ \\
\hline $\begin{array}{l}\text { Okudan et al., (2012) } \\
\text { and Philip (2012) }\end{array}$ & $\begin{array}{l}\text { Investigatedadvantages of component end-of-life option (i.e., reuse, recycle, } \\
\text { disposal)for supply chain implications. }\end{array}$ \\
\hline
\end{tabular}

Accordingly, design for manufacturing, design for remanufacturing, product sustainability, and supply chain optimization are used to classify prior work and they are briefly discussed below.

\subsection{Design for Manufacturing}

A recent review by Chiu and Okudan 2011 and Chiu and Okudan Kremer (2011b)identified 17 different tools (guideline sets, metrics, and methods) for DfM and DfA implementation; these two concepts are found to be most mature among all DfX concepts. For example, Stoll (1988) described strategy-based and practice oriented 13 DfM guidelines focusing on: (1) modular design, (2) multi-use parts with standardization, and (3) ease of assembly to increase the manufacturability. Fabricius (1994) proposed a set of guidelines, defining a "seven step procedure for design for manufacture," to enhance the linkage between design and manufacturing using a metrics-based model.Other methods include, but not limited to, the assembly-oriented design process (AODP) method (Warnecke and Bäbler 1988), the assembly evaluation method (AEM) by Boothroyd and Alting (1992), and the design for manufacture and assembly (DfMA) method (Boothroyd 1994).

The efficiency considerations of DfA and DfM can contribute to sustainable product design. For example, it was seen that the product design (e.g., bicycle)with the lowest DfA index was also the one with the lowest carbon footprint (Philip et al., 2013). In general, however, modular products might result in increased part counts and variable costs (Ulrich and Tung 1991). Despite this fact, DfA might be compatible with design for disassembly (DfD) after addition of environmental criteria, such as ease of removal and selection of recyclable materials (Harjula et al., 1996). DfM and DfA tools, in general, optimize the product architecture for assembly time and cost, and do not take into account environmental sustainability performance metrics.

\subsection{Design for Remanufacturing}

Remanufacturing is the practice of disassembling, cleaning, refurbishing, replacing parts (as necessary) and reassembling a product in such a manner that the part is at least as good as, or better than new (Bras and Hammond 1996). Design for disassembly (DfD) is a natural extension of design for assembly (DfA) and is one aspect of design for remanufacturing (DfRem). Economic benefits of DfRem, in addition to ecological benefits, stem from avoidance of reprocessing and manufacturing expenditures (Amezquita et al., 1995; Berko-Boateng et al., 1993; Guide Jr. 2000; Haynsworth and Lyons 1987; Navin-Chandra 1993). Design is the stage that has the strongest influence on environmental impact and also sets the product's capabilities (Eyring 1992; Ijomah et al., 2007a) and products that incorporate DfRem principles can display greater economic, environmental, and social benefits to manufacturers and society than remanufacturing strategies as an afterthought to product design (Nasr and Hilton 2008).Many 
products are not remanufacturable(Ferrer 2001) and designers, in general, face a paucity of remanufacturing knowledge and research information (Guide Jr. 2000). Accordingly, there is an urgent need for tools and methods to assist in the integration of environmental considerations into product design (Nissen 1995).

Remanufacturability can be enhanced using remanufacturability-specific design guidelines (DfRem) and by applying, individually or in combination, other design for $\mathrm{X}$ (DfX) practices(Ijomah et al., 2007b). In particular, design for environment (DfE) can be particularly applicable to remanufacturing, e.g., End-of-Life Adviser (ELDA) (Rose, Stevels, and Ishii 2000)and the reverse fishbone diagram (Ishii and Lee 1996). REPRO ${ }^{2}$ is a tool for assessing the remanufacturability of proposed designs via comparison to currently remanufacturable products(Gehin, Zwolinski, and Brissaud 2008). Sundin (2001) offered guidelines for enhancedremanufacturability by analyzing household appliances. Sundin and Bras (2005)concluded that cleaning and repairing are the most critical remanufacturing activities that can be facilitated through the development of the RemPro matrix. Amezquita et al. (1995)offered guidelines based on design features to identify design changes to improve automobile door remanufacturability. Bras and Hammond (1996) used DfA metrics as a foundation for remanufacturability assessment metrics based on product design features.

Examples of product architecture modifications for remanufacturing are numerous and varied (Zwolinski et al., 2006; Aguwa et al. 2011 and 2012). For example, Shu and Flowers (1995) focus on the architecture of three office products, and analyze the types of fasteners and joints that were originally designed for ease of assembly and recycling. Williams et al.(2000) analyzed toner-cartridge remanufactures' waste streams to suggest design alterations to enhance tonercartridge remanufacturability. Sherwood et al.(2000) studied an OEM's waste stream to develop a modified failure mode and effects analysis to facilitate remanufacturing. Mangun and Thurston (2002) presented a decision tool to help decide the most appropriate component end-of-life options. Ijomah et al. (2007a and 2007b) reported findings from a workshop undertaken in the UKon product design features that prevent the product or component from being remanufactured.

Overall, while effective case studies have been conducted for DfRem, it is apparent from the literature that robust and practical tools and processes are yet to be developed that effectively address and operationalize remanufacturing considerations during product design.

\subsection{Manufacturing Process Modeling and Sustainability}

Material and energy inputs and outputs of product manufacturing can be understood at their most fundamental level through process modeling (Kellens et al. 2012b; Kellens et al. 2012a). In turn, process inputs and outputs can be related to manufacturing cost, environmental impacts, and other performance measures. However, most process analysis techniques focus on specific cases or are conceptual (Hernandez-Matias et al., 2006), and traditionally have considered manufacturing cost, cycle time, productivity, labor, and flexibility, rather than other sustainability-related performance measures (e.g., environmental and community impacts). Recent developments have highlighted the need to integrate process analysis and decision support tools with engineering design and optimization tools. Lin and Polenske (1998)stressed the need for micro-level input-output process models for effective business decision-making due to the coarse resolution of existing national frameworks (e.g., EIO-LCA).Sutherland and Gunter (2001) described a method to establish such models: 1) Conduct a process inventory (Figure 1), 2) Quantify the input and output mass and energy flow rates, and 3) Describe the outputs as a function of the inputs. 


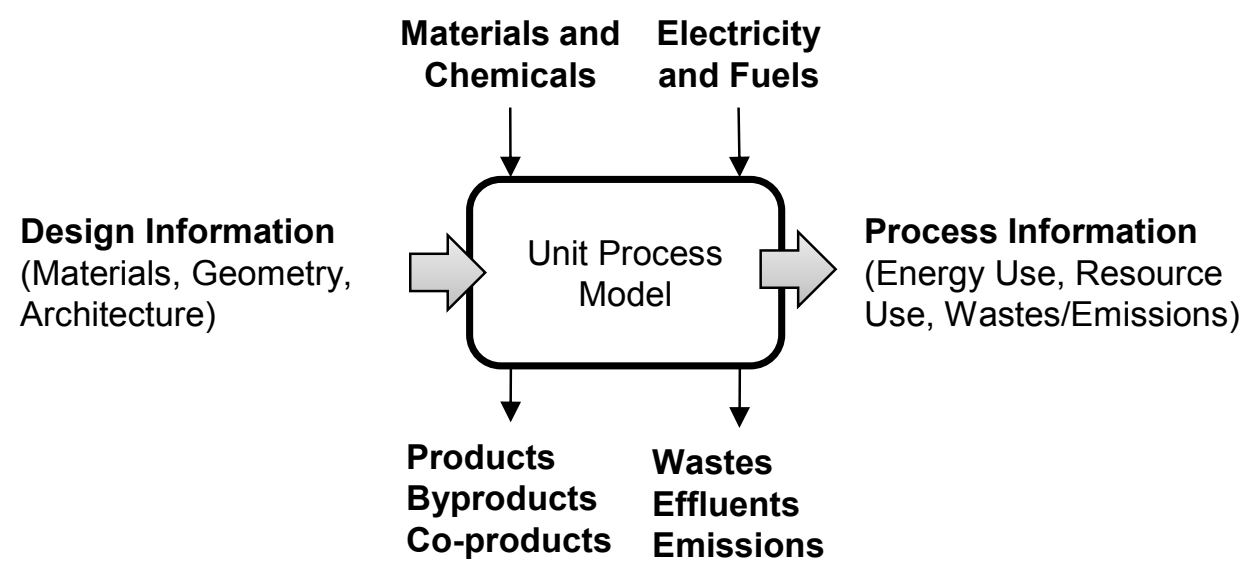

Figure 1. Unit Process Modeling Concept (afterNational Research Council (U.S.) 1995; Kellens et al. 2012b).

Kellens et al. (2012a) formalized a method for manufacturing process analysis to support LCA, identified in the US as unit process life cycle inventory (uplci) and in Europe as CO2PE!. They considered several machining processes to estimate energy consumption. Related work was demonstrated by Overcash et al.(2009) to quantify energy use for manufacturing processes. Eastlick et al.(2011) presented an approach to compare product design alternatives on the basis of environmental, economic, and social measures generated from process-based analysis. He et al. (2012) applied an event graph methodology for modeling machining task energy use from a manufacturing system perspective, which demonstrated the link between the process and system level. Process modeling studies have considered environmental performance, but exhibit uncertainties due to (Sheng and Worhach 1997): 1) measurement or data collection errors, 2) uncertainties in process modeling, 3) variability in the control volume because of externalities, 4) uncertainties in chemical composition and transport properties, 5) the qualitative nature of sitelevel factors, and 6) uncertainties in assessing user preferences in utility analysis. Collaborative academic and industrial research can serve to address many of the above cited manufacturing process modeling concerns, facilitate data gathering, and lead to more accurate, industrially relevant models. Initial work in this regard has been initiated by the National Institute for Standards and Technology in the U.S. (Mani et al., 2014).

\subsection{Supply Chain Optimization}

Research in the prevailing literature has found that supply chain performance cannot be optimized without considering the compatibility of product and supply chain attributes (Fisher 1997; Vonderembse et al., 2006). The integration of supply chain network design and product design promotes the concept of Design for Supply Chain Management (DfSCM). Lee and Sasser (1995)defined DfSCM as "having the goal to design products and processes to more effectively manage supply chain related cost and performance". Blackhurst et al.(2005) developed a Product Chain Decision Model to compare the benefit of supplier selection and information sharing according to bill of materials. Lamothe et al.(2006) presented a product family selection and supply chain design methodthat can optimize supply chain costs while choosing variant components based on a generic bill of materials. In general, there are six key approaches to DfSCM that increase efficiency and responsiveness of supply chains: Variety control (Thonemann and Bradley 2002), logistics enhancement, commonality and reuse (Doran 2003; 
Mikkola and Skjøtt-Larsen 2004), Postponement (Su et al., 2005; Yang et al., 2005; Mikkola and Skjøtt-Larsen 2004), tax and duty reduction, and facilitating reverse logistics.

The supply chain perspective is often considered at the detail design stage, final stage when much of the design flexibility has been removed. Relatively few studies consider the supply chain perspective early in product design (Yan, Yu, and Edwin Cheng 2003; Lamothe, HadjHamou, and Aldanondo 2006; Khalaf, Agard, and Penz 2008; ElMaraghy and Mahmoudi 2009; Laurent, Olsen, and Hauschild 2010; Khalaf, Penz, and Agard 2009; Chiu and Kremer 2014; Nepal, Monplaisir, and Famuyiwa 2011; Bush, Tiwana, and Rai 2010). There is no prior work, however, investigating the interplay between selection of design alternatives and life-cycle processes. Further, prior work mostly focuses on forward supply chains, and there is very limited work on closed-loop chains. Krikke et al.(2003) developed a model for product structure design considering modularity, reparability, and recyclability and logistics network design for a Japanese consumer electronics company. LCA has been proposed to evaluate environmental impacts associated with products, processes, and activities (De Benedetto and Klemeš 2009).

A number of studies considered environmental impacts of supply chain designs (Hugo and Pistikopoulos 2005; Ramudhin et al., 2008; Ramudhin et al., 2009; Frota Neto et al., 2008; Guillén-Gosálbez and Grossmann 2009; Chaabane et al., 2012). Several studies considered carbon footprint in sourcing, inventory, and distribution processes (Zsidisin and Siferd 2001; Sourirajan et al. 2009; Bonney and Jaber 2011; Hoen et al. 2010; Pan, Ballot, and Fontane 2013; Reuter et al. 2010; Zhu, Dou, and Sarkis 2010) In general, however, there is a significant gap in capturing the economic and environmental sustainability of forward and reverse supply chain implications of product design variants (Ilgin and Gupta 2010). As Gan and Grunow (2013) attest, however, “... researchers in product design (PD) and supply chains (SC) management have kept mainly within their domains for various reasons such as complexity of crossdisciplinary research..." These findings motivate an integration of supply chain decisions and product design decisions, including costs and environmental impacts, so that the optimal component acquisition and supply chain alternatives can be determined and evaluated in the earlier product design stages.

\section{Promising Foci for Instilling Sustainability across Product Supply Chains}

Based on our review, we postulate that the development of supply chain models that account for the dependencies between product design, manufacturing, and supply chain decisions to minimize cost and environmental impacts (e.g., carbon footprint)can be enabled through the concepts of integral, modular, and hybrid product architectures, as well as manufacturing process and assembly analyses. The research community addressing the economic and environmental sustainability across product supply chains is mostly organized around four thrusts: 1) Sustainability through effective product development processes/practices, 2) Sustainability through effective manufacturing processes/practices, 3) Sustainability through effective supply chain processes/practices, and 4) Sustainability through effective and integrated consideration of life-cycle processes.Given our primary interest in addressing sustainability at the earliest stages of the product life cycle, in particular product development, we have identified four distinct foci for further investigation and exploitation to improve the sustainability in product supply chains, which we discuss in detail below.This is not to suggest that there aren't other gaps or opportunities for promoting sustainability. Our focus is on opportunities for action at the front end of the product life cycle. 


\subsection{FOCUS AREA1: Reengineering the Product Architecture to Match the Intended Product End-of-Life Option}

The use of modular design is gaining popularity in industry with several successful cases of implementation reported in the literature; however, the science to support modular product architecture is still evolving(Gupta and Okudan 2008). For example, a recent study by Kremer and Gupta (2013) shows that modularization of the same product using three different modularity approachesresults in different product architectures. Another study by Nepal et al.(2011) introduces the use of a multi-objective optimization model in configuring the supply chain during modular product development. In addition to using various production and inventory costs, the model makes use of subjective criteria such as alignment of business practices and financial objectives of member companies in configuring the supply chain.

An opportunity exists for purposefully architecting the product design so that design for manufacturing, design for remanufacturing and design for sustainability can be achieved; we note, however, experimentation is needed with different modularization methods, and in varying modularization levels. Among the relevant research questions are: 1) Can a modular structure where components are clustered according to reuse or recycling objectives positively impact sustainability measures (e.g., cost and carbon footprint)?; 2) Can an increased level of modularity positively impact sustainability measures across the supply chain?; and3) What is the impact of product architecture and platform decisions early in product development on supply chain sustainability measures? The research to provide insights into these questions can be challenging especially in the design of breakthrough and innovative products. Defining sustainability and remanufacturability targets early in the design of a product can be difficult when requirements and design specifications are still evolving. Some attempts (Nepal et al., 2011; Ülkü and Schmidt 2011; Chung et al., 2011) have been made at a holistic design approach but the science is still evolving.

Ülkü and Schmidt (2011) have found analytically that supplier relationship and product architectural design are interdependent. However, to our knowledge, there are not any mathematical models available in the prior literature that quantifies the influence of product architecture design on supply chain configuration considering sustainability metrics. Another notable gap is the lack of consideration of the environmental compatibility of partners into the SCM decisions. While individual companies are increasingly embracing environmentally compatible logistics, such as reduction or avoidance of transport, increased capacity utilization and mass transportation, recycling and reusable packaging, and coordinating with their logistics service providers, these efforts often do not extend to their other SCM partners nor to their other SCM functional areas. The developmentof robust models to address this deficiency through a multi-objective optimization model is necessary.

Newcomb et al.(1998) stated that the modularity of a product influences its initial cost, ease of service (assembly and disassembly), and effort required to retire the product (reuse, recycling, and disposal). As discussed previously, in general, modular products need to be designed with redundant physical components and limited function sharing for compatibility across other products, which might result in increased part numbers and variable costs (Ulrich and Tung 1991). Future work relevant to this focus area should take into account minimization of cost and environmental impact by clustering components based on their design intent forreuse, recycling, and service. For this purpose, the components of the designed product can be first represented 
through a connectivity graph, and then the graph can be partitioned based on modularity for sustainability (see Figure 2) (Chung et al. 2011).

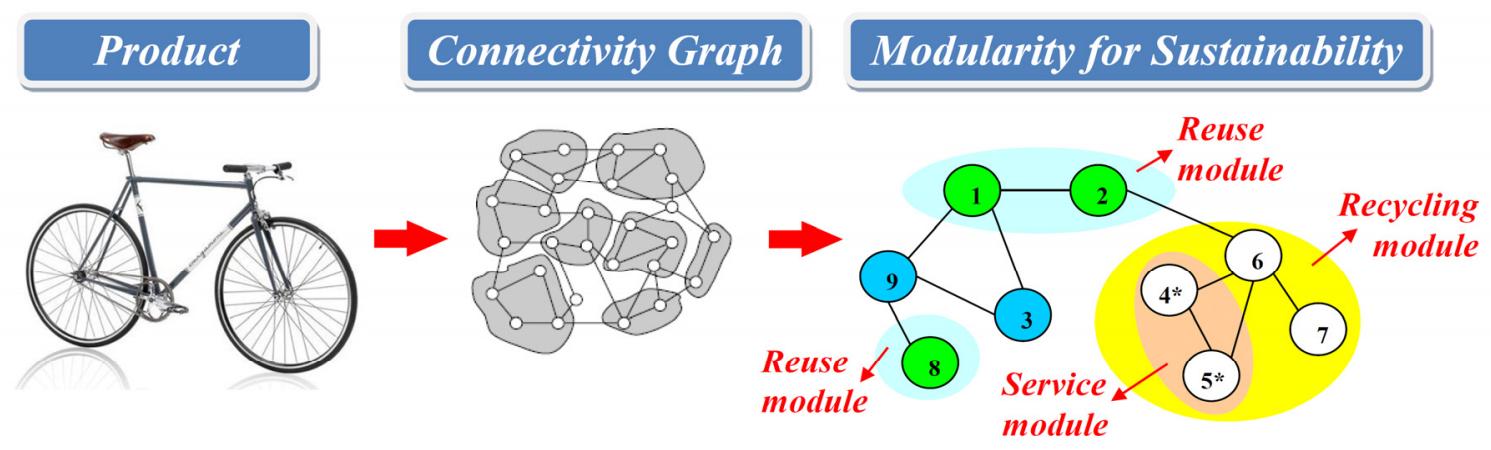

Figure 2. Modularity for Sustainability(Adapted from Chung et al., 2011)

Future work on product architectures that are engineered, or reengineered for increased sustainability should enlist support from industry partners, as credibility of the information used during the investigation is paramount. This information pertains to components and feasible configurations of the product architecture, for which the full set of concept combinations (product architecture variants) with varying levels of modularity and supplier options for each product (sub-assembly) component and modular design permutations can be studied.

\subsection{FOCUS AREA2: Assembly/DisassemblyOperation Modeling and Analysis for Environmental Sustainability}

Joints are inevitable in product architecture because of constraints on component geometric configuration. Other limitations include material properties and the requirements of inspection, accessibility, repair, portability, and recyclability (Kim et al. 2004). Defining joining components provides a way of realizing simpler forms of the individual components of products, which affect assembly cost and environmental impacts related to assembly and disassembly operations. The environmental effects of assembly operations and assembly component selection are often excluded, however, in previous research efforts (e.g., Rajemi et al. 2010; Pusavec et al. 2010).Balancing the design and environmental requirements, and selecting an optimal assembly method is a complicated process. For example, welded or mechanically fastened (or riveted) joints have been considered as alternatives for an automotive frame design. Conventionally, welded joints have been preferred in frame manufacturing, due to complex geometries and cost efficiencies. Traditional trade-off analyses focus on heat affected zones, which are potential sources of structural crack propagation. However, the environmental pollutants (e.g., fumes and gases) caused by the welding operation often receive little attention in design stage joining decisions(Fleischer and Schaedel 2013; Miller et al. 2010). A mechanically fastened joint could eliminate these pollutants; however, it will cause other design changes (e.g., bonding effects of rivets).Thus, a balanced decision supporting tool should be able to analyzecost and environmental sustainability performance of different assembly operations, to consider tradeoffs of objectives (e.g., cost vs. recyclability) without sacrificing the functional design requirements, andto balance the design and environmental requirements.

To consider assembly operation implications for design requirements and environmental sustainability should be considered simultaneously. The evaluation of all possible assembly operation alternatives is costly. Thus, high quality/feasible assembly operation alternatives should be selected before detailed analysis occurs. For this, meta-heuristics algorithms (e.g., 
neural networks and genetic algorithms) can be used to generate a set of feasible assembly operation alternatives. The alternatives require comprehensive evaluation processes to determine whether they satisfy the design and environmental requirements. Although several methods exist to aid final decision making, due to the ill-structured nature of most design requirements, analytic and semantic network methods have been investigated. Bock et al. (2010)adopted an ontology to capture alternative designs and incremental refinements. Their model-based techniques support the use of ontologies for flexible design combination, refinement, and consistency checking. Choi et al.(2011)presented a schema to represent design knowledge networks. Their schema is used to determine which functions or structures of products are able to meet design requirements for new design alternatives in consideration of hybrid products. They employ a rough set technique to identify a pattern of latent rules in the schema. Chungoora and Young (2008) address the problem of ontology heterogeneity and propose ontology mapping techniques. Semantic mismatches between heterogeneous ontologies are specifically considered and the disparate characteristics of ontologies are highlighted. Kim et al.(2008a) developed assembly design rules to support ubiquitous smart device design collaboration and to highlight cumulative, evolutionary design information challenges. They presented a rough set approach to extract the appropriate minimal rules among the demanded rules associated with physical assembly component design.

Kim et al.(2008b)developed a formal method for differentiating assembly joints. They highlighted the current limitation of attached notes and annotations to geometric entities that distinguish joints. By introducing the concept of mereotopology, the differences of joints, assembly design terms, and their relationships are segregated. Also, Kim et al. (2009) usedan ontology to represent morphological characteristics related to assembly joints, which are consequences of the principal physical processes and of the design intentions. Kim et al.(2008c)demonstrated the feasibility of a semantic hierarchical network method to support assembly design decision making. In their method, multiple semantic networks establish a hierarchical network for assembly operation analysis.

\subsection{FOCUS AREA 3: Manufacturing Process Modeling for Sustainability Assessment}

Unit manufacturing processes utilize mechanical, thermal, and/or chemical energy to alter material input(s) into a desired output (e.g., a product component). These unit processes are linked to form production systems for new products, or to formreverse production systems to remanufacture end-of-life (EOL) products. Mathematical models of unit manufacturing processescan be used in design to quantify and reducematerials and energy use and wastes and emissions, while enhancing productivity and reducing costs(Arinez et al. 2010). The relevant research questions for consideration in this focus area include: (1) How do design variants impact supply chain sustainability measures (e.g., cost and carbon footprint) through materials, manufacturing processes, and assembly operations?; and (2) How are these sustainability measures impacted by manufacturing and assembly locations (e.g., energy sources in China vs. Belgium)?

To develop such understanding, there are myriad manufacturing processes to consider. Thus, development of process modelscould begin withconventional manufacturing processes (e.g., cutting, forming, and injection molding) using traditional materials (e.g., metals and polymers), with the collaboration of industry.Industry can provide access to datathat supports empirical model development and validation of physics-based or mechanisticmodels. In addition, process models should consider direct (e.g., process generated) and indirect (e.g., due to electricity) 
emissions to capture impacts holistically. In particular, process models can parametrically relate design parameters (e.g., materials and geometry) to process characteristics. Thus, changes to and sensitivity of manufacturing-related economic and environmental sustainability measures can be evaluated for the design variants.

As introduced above, the importance of carbon footprint as an environmental performance measure for manufacturing activities has been reported widely (Laurent et al. 2010; Boguski 2010; Jeswiet and Nava 2009; Joyce et al. 2010). Using a microeconomic model,Branker et al.(2011) linked the reduction of energy consumption and the associated carbon footprint to the reduction of manufactured product total cost. Fang et al. (2011) investigated linear programming to optimize the peak power load and energy use of manufacturing systems. Ibbotson and Kara (2011) examined a dozen supply chain network designs subject to various transportation modes and routes, loads to be transported, and energy profile per location. Chiu et al. (2010)combined a graph theory approach for generating product design concepts with LCA to simultaneously account for cost and carbon footprint at the product development phase.

Work in this focus area is needed foremost for improving data quality and process model scalability for predictive sustainability analysis (Mani et al. 2014).Specifically, parametric unit process models will address several problems with LCA-based approaches in predicting product environmental impacts, which include (Reap et al., 2006): 1) limited spatial resolution, 2) lack of dynamics, 3) neglecting existing levels of pollution and eventual pollutant disposition, 4) use of linear process models, and 5) reliance on value judgments and subjectivity. By interfacing with the semantic reasoning and supply chain optimization methods described below, researchwill lead to fundamental, science-based process models linked with design and production system information to inform early stage design activities about manufacturing and assembly sustainability performance.

\subsection{FOCUS AREA 4: Joint Optimization of the Best Subset of Design Variants with Mathematical Models of Life Cycle Processes}

Building on the existing set of models in DfSCM, the joint optimization of design and lifecycle processes must be extended by including the reverse logistics costs, energy efficiency and emissions. While the large number of bill of material (BOM) alternatives in the early concept phase makes it prohibitive to consider as part of DfSCM efforts(Taghavi 2012; Taghavi and Chinnam 2014), the accounting for environmental sustainability in addition to standard supply chain cost models and metrics further makes this complexity even more serious(Umpfenbach 2013). Hence, one main component of this focus area might be to develop novel optimization methods to address these challenges.

The main advantage in aligning supply chain network design and cost decisions with sustainability is to allow more effective decisions while understanding what the tradeoffs are between economic and environmental performance. Accordingly, novel optimization methods would enable answering such critical research questions as:1) What is the impact of joint consideration of design variant selection, supply chain configuration, and optimization of lifecycle processes on economic and environmental sustainability?; and 2) What is the Pareto frontier as a result of trading supply chain metrics and environmental metrics including carbon 
footprint of materials used, emissions from selected manufacturing processes and supply chain operations, and in the creation of the energy used?

As described above, carbon footprint predictions can be incorporated into forward and reverse supply chainmodels through the selection of the energy source for each process. The GHG Protocol Corporate Standard, which is widely used for companies to quantify and report GHG emissions in three levels of scope,as shown in Figure 4 (GHG, 2011), can be used to capture the effects of all supply chain and life cycle processes. Scopes 1 and 2 represent direct emissions due to the company's operations and scope 3 represents all other indirect emissions, including upstream and downstream emissions. Scope 1 primarily corresponds to manufacturing, assembly, and related transportation operations. Scope 2 corresponds to emissions from the generation of purchased or acquired electricity, steam, and heating or cooling consumed by the company. Scope 3 emissions include upstream activities such as the production of goods and services purchased by the company, as well as downstream activities such as disposal of products.For scope 2, publicly available and private company data for cost and emission information can be used. For instance, the location decisions for manufacturing, distribution and logistics facilities can be evaluated using the Green Power Network (GPN) by the U.S. Department of Energy, which illustrates the green utility pricing programs per state (Green Power 2014). The resultant models can then include supply chain configuration decisions where the company can select the composition of energy sources for scope 2 emissions. Overall, including energy source portfolio decisions allows trading-off emissions and cost of energy and provides more flexibility in managing the economic and environmental sustainability across product supply chains.

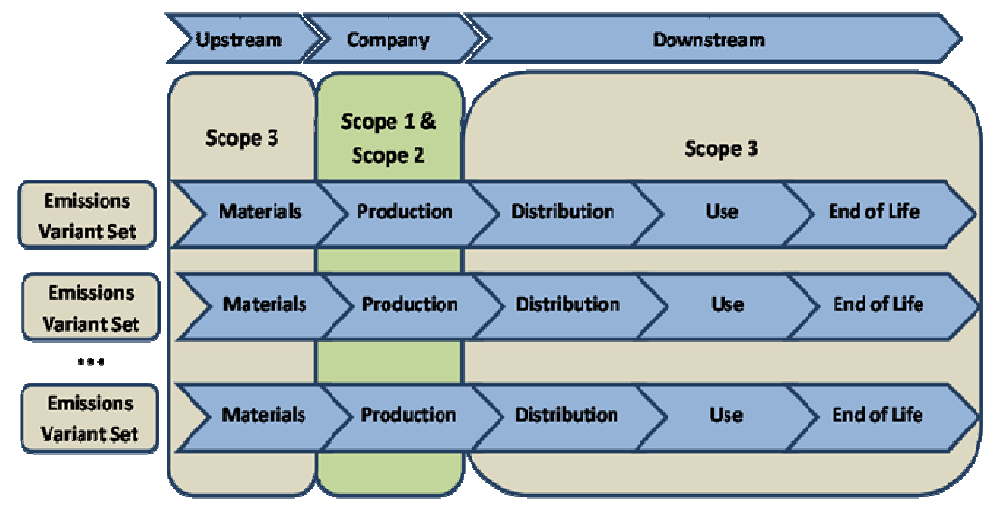

Figure 4. Joint Optimization across the Supply Chain and Product Life Cycle

Due to the computational complexity, a hierarchical approachwould be a more effective approach for this focus area. This approach allows obtaining feasible and good solutions at the highest level of product structure representation by using multilevel (hierarchical) optimization methods, where the state of the art for integer models is evolving (Chinchuluun et al., 2009; Colson et al., 2007; Dempe 2002; Gümüş and Floudas 2005). Hierarchical models are used in many real-world problems that involve hierarchical relationships between multiple decision levels such as management (e.g., regulation for environment, energy policy, and hazmat) and economic planning (e.g., pricing and regulation for electric power). The hierarchical optimization methodology consists of mathematical formulations representing the interdependency between the design variants, product configurations and lifecycle processes, including remanufacturing and reverse logistics operations. For instance, any two product variant 
sets selected will correspond to different forward and reverse supply chain designs, as well as carbon footprints.

\section{Preliminary Work to Instill Sustainability across Product Supply Chains}

Preliminary work addressing the above focus areas proposed a novel Geographic Information Systems (GIS)-based hierarchical decision framework(Lei 2013).A company first defines regions around the globe from which to select suppliers. Subsequently, suppliers and network designs are evaluated using goal programming. This hierarchical decision framework is facilitated through a software tool, the Supply Chain Network (SCN) Design System, which uses the Java language within the Eclipse programming environment and incorporates Geotools, WorldWind, and the OptimJ Glpk solver (see further details on the software in Lei and Okudan Kremer, 2013).

The preliminary work presented below applies the SCN Design System and extends our earlier work to optimizecost and/or carbon footprint while making integrated product architecture and supply chain decisions (Chiu et al., 2009; Chiu and Okudan 2011). The tradeoffs among supply chain cost, lead time, and carbon footprint were also investigated (e.g., Olson 2010; Olson et al., 2011).In the prior work, a set of suppliers was selected by evaluating their impact on both internal (e.g., ease of assembly) and external (e.g., transportation and lead time) enterprise performance measures, which are aggregated to indicate supply chain performance at the conceptual design stage. A case study inthe bicycle industrydemonstrated the advantages of integrating design and supply chain design decisions. The synchronized structure of supply chain and product designs resulted in simultaneous optimization of both during the early stages of design (Chiu and Okudan 2011). Despite its contributions to the state-of the art, our earlier work had one important limitation: information specific to the region of the suppliers was neglected. With this work here, a path to mitigate this limitationis provided.

The proposed two-stage SCN Design System consists of region-based and company-based selection phases. The goal is to simultaneously optimize cost, carbon footprint, product quality, and delivery reliability by considering geographical influences. The first phase generates desired supplier regions based on World Bank country performance indices. In the current version of the software, four World Bank country performance indices are used: (1) Global competitiveness, (2) Ease of doing business, (3) Enabling trade index, and (4) Logistics performance index. These were chosen for their potential impact on global supply chains. In the software, the user is asked to rank the importance of these factors, and subsequently, countries are filtered to shorten the list down to a more manageable set of countries.

The second phase employs a mixed integer programming (MIP) model to determine suitable suppliers and purchasing quantities. We integrate the MIP model with GIS to provide aflexible decision support system for the management teams. Geotools and WorldWind were chosen for their advantages to render GIS Shapefile data and to construct a customized user interface. OptimJ Glpk solves the MIP model using goal programming. While objectives are summarized below, the whole model along with notations are provided byLei (2013).

Z1: minimize the total cost;

Z2: minimize the rejection due to the quality problem;

Z3: minimize the total deviations from due date of delivery;

Z4: minimize total carbon footprint. 
Budget, demand, suppliers' capacity, and a carbon emission cap are considered as constraints. This approach assumes that the objective to minimize the total cost (Z1) has the highest priority, followed by Z2, Z3, and Z4. Each objective serves as a single objective in the model, and after obtaining the optimal values, each objective will act as a constraint in next round of calculations. This method converts these multiple criteria objectives with preemptive priorities to separate single objective problems. The information obtained for candidate suppliers is displayed and stored in the MySQL database for future use.

Table 3. Recommended Suppliers with Order Lot Sizes and Optimized Result

\begin{tabular}{|c|c|c|c|c|c|c|c|c|c|c|c|}
\hline ID & Supplier & [A]Saddle & [B]Frame & [C]Fork & [D]Brake & [E]Wheels & [F]Trans & {$[\mathrm{AB}]$} & {$[\mathrm{CD}]$} & [EF] & [DEF] \\
\hline 1 & X-bike & & 9180 & & & & & & & & \\
\hline 2 & ADK & & & 9000 & & & & 1430 & & & \\
\hline 3 & Advanced & & & & & & & & & & \\
\hline 5 & SRAM & & & & 6770 & & & & 2000 & & \\
\hline 6 & Vello & 7239 & & & & & & & & & \\
\hline 7 & Viscount & 2346 & & & & & & & & & \\
\hline 10 & Tien Hsin & & & & & & 8015 & & & & \\
\hline 11 & Shimano & & & & 1925 & & & & & 1280 & \\
\hline 12 & Spinner & & & & & 8136 & & & & & \\
\hline 13 & Formula & & & & & 800 & & & & & 1005 \\
\hline & Engin & & & & & & & & & & \\
\hline \multirow{2}{*}{\multicolumn{2}{|c|}{$\begin{array}{l}\text { Optimized } \\
\text { Results }\end{array}$}} & & Total Cost & & \multicolumn{2}{|c|}{ Rejected Product } & $\begin{array}{l}\text { Deviatior } \\
\text { Due Date }\end{array}$ & from & \multicolumn{2}{|c|}{$\begin{array}{l}\text { Total Carbon } \\
\text { Footprint }\end{array}$} & \\
\hline & & & 6007835 & & 1034 & & 49073 & & 700 & & \\
\hline
\end{tabular}

Using the SCN Design System and the data relevant to the earlier bicycle case study (presented in Appendix Tables A1-A4), a sample case is solved and its results are presented below. X-bike is the bicycle company analyzed in this case study to manufacture a final product with an estimated total annual demand of 10,000 units and a monthly budget of $\$ 8$ million. The region-based selection stage determines 12 candidate suppliers based on their aggregated index and technological capability. Relevant to these suppliers, component (Table A1) and module (Table A2) based unit costs, unit order costs, average defect rates, average delivery delays and maximum supply quantities are provided. Tables A3 and A4 provide the carbon footprints, calculated using SimaPro LCA software (Philip et al., 2012). Table 3 summarizes the results.

Despite showing the potential of simultaneous optimization of product architecture and supply chain decisions, this preliminary work has several significant shortcomings:

1) It does not exploit potential modularity considerations for reduced environmental impact. End-of-life options of components or modules (e.g., dispose, reuse, or recycle) have not been taken into account.

2) It does not consider potential implications of manufacturing and assembly process level decisions on product economic and environmental sustainability. It simply considers the modeled carbon footprint for each component option; thus, what-if analyses considering alternative manufacturing processes is not possible.

3) Although the geographic region of production and, hence, the type of the energy source used in environmental impact (i.e., carbon footprint) projections is taken account, the model does not include closed loop supply chain issues (e.g., DfRem). 


\section{Future Research, Recommendations and Conclusions}

While the research community has recognized and begun to address the challenges of product life cycle economic and environmental sustainability, much work remainsbefore operational methods and tools can emerge to assist design engineers and other supply chain decision makers in sustainable product design and manufacturing. Understanding and quantifying dependencies between costs and environmental impacts and product design, manufacturing, and supply chain decisions are critical to the development of such methods and tools. In exploiting these dependencies, special emphasis should be given to product architecture (e.g., integral, modular, and hybrid), as well as to manufacturing process and assembly/disassembly processes. Research opportunities are outlined below with respect to the four focus areas discussed above. This list is not intended to be comprehensive, but rather aims to serve as direction and guidance for addressing immediate opportunities.

FOCUS AREA 1: Reengineering the Product Architecture to Match the Intended Product End-of-Life Option

FOCUS AREA 2: Assembly/Disassembly Operation Modeling and Analysis for Environmental Sustainability

FOCUS AREA 3: Manufacturing Process Modeling for Sustainability Assessment

FOCUS AREA 4: Joint Optimization of Design Variants with Mathematical Models of Life Cycle Processes

In the foregoing sections, we examinean integrated view of decision making in product design, manufacturing,and supply chain operations, under the lens of sustainability. Although a critical mass of relevant work exists,by and large, prior research has had a narrow scope (e.g., solely considering manufacturing processes or supply chain operationsalong with one or a few sustainability performance metrics), limiting the potential gainsfor design decision support. Based on the review of the literature, we recommend integrated, synergistic investigations in the aforementionedfour research focus areas in addition to research addressing gaps in each area, individually.In our preliminary example, where we studied the cost and carbon footprint tradeoffs in a bicycle supply chain, results point to the above articulated need forintegrating design, manufacturing, and supply chain decision making.Many of ourrecommendations are pointed toward developing and operationalizing engineering methods and tools, however, sustainability decisions are often reliant on qualitative assessments made by teams of leaders comprising expertise across an organization (e.g., marketing, business strategy, corporate responsibility, and worker health and safety). Thus, future research must ultimately develop methods to integrate quantitative and qualitative decision-making methods.

\section{Acknowledgments}

We thank Mr. Hamed Seyedmahmoudi for his assistance in manuscript preparation. We gratefully acknowledge the support of this work by the National Science Foundation under grant numbers OCI-1041423 (Oregon State), OCI-1041328 (Penn State), and OCI-1041380 (Wayne State).

\section{References}

Aguwa, C., L. Monplaisir, and O. Turgut. 2011. "Collaborative Modular Architecture Framework for Design Evaluation Method of Reusable Medical Equipment." In Portland 
International Conference on Management of Engineering Technology, 2009. PICMET 2009. Charlotte.

Aguwa, Celestine C., Leslie Monplaisir, and Prasanth Achuthamenon Sylajakumari. 2012. "Rules Modification on a Fuzzy-Based Modular Architecture for Medical Device Design and Development." IIE Transactions on Healthcare Systems Engineering 2 (1): 50-61. doi:10.1080/19488300.2012.666630.

Amezquita, Tony, Rick Hammond, Marc Salazar, and Bert Bras. 1995. "Characterizing the Remanufacturability of Engineering Systems." In ASME Advances in Design Automation Conference, 271-78.

Anastas, Paul T., and Julie B. Zimmerman. 2003. "Design Through the 12 Principles of Green Engineering." Environmental Science \& Technology 37 (5): 94A-101A. doi:10.1021/es032373g.

Appelqvist, Patrik, Juha-Matti Lehtonen, and Jukka Kokkonen. 2004. "Modelling in Product and Supply Chain Design: Literature Survey and Case Study." Journal of Manufacturing Technology Management 15 (7): 675-86. doi:10.1108/17410380410555916.

Arinez, Jorge, Stephan Biller, Kevin Lyons, Swee Leong, Goudong Shao, B. E. Lee, and John Michaloski. 2010. "Benchmarking Production System, Process Energy, and Facility Energy Performance Using a Systems Approach." In Proceedings of the 10th Performance Metrics for Intelligent Systems Workshop, 88-96. PerMIS '10. New York, NY, USA: ACM. doi:10.1145/2377576.2377593. http://doi.acm.org/10.1145/2377576.2377593.

Baumann, H., F. Boons, and A. Bragd. 2002. "Mapping the Green Product Development Field: Engineering, Policy and Business Perspectives." Journal of Cleaner Production 10 (5): 409-25. doi:10.1016/S0959-6526(02)00015-X.

Berko-Boateng, V., J. Azar, E. De Jong, and G.A. Yander. 1993. "Asset Cycle Management-a Total Approach to Product Design for the Environment." In , Proceedings of the 1993 IEEE International Symposium on Electronics and the Environment, 1993, 19-31. doi:10.1109/ISEE.1993.302843.

Bicycle.net. 2010. "Bicycle Manufacturer Directory." Bicycle.net | Bicycle Manufacturer Directory. http://www.bicycle.net/resources/bicycle-manufacturer-directory.

Blackhurst, Jennifer, Tong Wu, and Peter O'Grady. 2005. "PCDM: A Decision Support Modeling Methodology for Supply Chain, Product and Process Design Decisions." Journal of Operations Management 23 (3-4). Coordinating Product Design, Process Design and Supply Chain Design Decisions: 325-43. doi:10.1016/j.jom.2004.05.009.

Bock, Conrad, XuanFang Zha, Hyo-won Suh, and Jae-Hyun Lee. 2010. "Ontological Product Modeling for Collaborative Design." Advanced Engineering Informatics 24 (4). Construction Informatics: 510-24. doi:10.1016/j.aei.2010.06.011.

Boguski, Terrie K. 2010. "Life Cycle Carbon Footprint of the National Geographic Magazine." The International Journal of Life Cycle Assessment 15 (7): 635-43. doi:10.1007/s11367010-0210-5.

Bonney, Maurice, and Mohamad Y. Jaber. 2011. "Environmentally Responsible Inventory Models: Non-Classical Models for a Non-Classical Era." International Journal of Production Economics 133 (1). Leading Edge of Inventory Research: 43-53. doi:10.1016/j.ijpe.2009.10.033.

Boothroyd, G., and L. Alting. 1992. "Design for Assembly and Disassembly." CIRP Annals Manufacturing Technology 41 (2): 625-36. doi:10.1016/S0007-8506(07)63249-1. 
Boothroyd, Geoffrey. 1994. "Product Design for Manufacture and Assembly." Computer-Aided Design 26 (7): 505-20. doi:10.1016/0010-4485(94)90082-5.

Branker, K., J. Jeswiet, and I.Y. Kim. 2011. "Greenhouse Gases Emitted in Manufacturing a Product-A New Economic Model.” CIRP Annals - Manufacturing Technology 60 (1): 53-56. doi:10.1016/j.cirp.2011.03.002.

Bras, B., and R. Hammond. 1996. "Towards Design for Remanufacturing - Metrics for Assessing Remanufacturability." In Proceedings of the 1st International Workshop on Reuse ,, 5-22. Eindhoven, The Netherlands.

Bush, Ashley A., Amrit Tiwana, and Arun Rai. 2010. "Complementarities Between Product Design Modularity and IT Infrastructure Flexibility in IT-Enabled Supply Chains." IEEE Transactions on Engineering Management $57 \quad$ (2): 240-54. doi:10.1109/TEM.2010.2040741.

Chaabane, Amin, Amar Ramudhin, and Marc Paquet. 2011. "Designing Supply Chains with Sustainability Considerations." Production Planning \& Control 22 (8): 727-41. doi:10.1080/09537287.2010.543554.

Chinchuluun, Altannar, Panos M. Pardalos, and Hong-Xuan Huang. 2009. "Multilevel (Hierarchical) Optimization: Complexity Issues, Optimality Conditions, Algorithms." In Advances in Applied Mathematics and Global Optimization, edited by David Y. Gao and Hanif D. Sherali, 197-221. Advances in Mechanics and Mathematics 17. Springer US. http://link.springer.com/chapter/10.1007/978-0-387-75714-8_6.

Chiu, M.C., S. Gupta, and G.E. Okudan. 2009. "Integration of Product Structure and Supply Chain Decisions at the Conceptual Design Stage: A Repository Enabled Decision Tool." In International Design Engineering Technical Conferences. San Diego, CA.

Chiu, Ming Chuan, and Gul E. Okudan Kremer. 2011. "Investigation of the Applicability of Design for X Tools during Design Concept Evolution: A Literature Review." International Journal of Product Development 13 (2): 132-67. doi:10.1504/IJPD.2011.038869.

Chiu, Ming-Chuan, Ahmed J. Alsaffar, Gul E. Okudan, and Karl R. Haapala. 2010. "Reducing Supply Chain Costs and Carbon Footprint during Product Design.” In , 1-6. Washington D.C, USA: IEEE. doi:10.1109/ISSST.2010.5507711. http://ieeexplore.ieee.org/lpdocs/epic03/wrapper.htm?arnumber=5507711.

Chiu, Ming-Chuan, and G.E.O. Kremer. 2014. "An Investigation on Centralized and Decentralized Supply Chain Scenarios at the Product Design Stage to Increase Performance." IEEE Transactions on Engineering Management 61 (1): 114-28. doi:10.1109/TEM.2013.2246569.

Chiu, Ming-Chuan, and Gül Okudan. 2011. "An Integrative Methodology for Product and Supply Chain Design Decisions at the Product Design Stage." Journal of Mechanical Design 133 (2): 021008-021008. doi:10.1115/1.4003289.

Choi, J. K.Nies, L.F Nies, and K Ramani. 2008. "A Framework for the Integration of Environmental and Business Aspects Toward Sustainable Product Development." Journal of Engineering Design 19 (5): 431-46. doi:10.1080/09544820701749116.

Choi, K., K.Y. Kim, and H.J. Yang. 2011. "Set Approximation Based Combinatorial Search for Interaction Network-Based Conceptual Design." Journal of Integrated Design \& Process Science 15 (2): 1-15. 
Chung, W.H., G.E. Okudan, and R.A. Wysk. 2011. "Modular Design to Optimize Product Life Cycle Metrics in a Closed-Looped Supply Chain." In Industrial Engineering Research Conference. Reno, NV.

Chungoora, N., and R.I.M. Young. 2008. "Ontology Mapping to Support Semantic Interoperability in Product Design and Manufacture." In The First International Workshop on Model Driven Interoperability for Sustainable Information Systems. Montpellier, France.

Colson, Benoît, Patrice Marcotte, and Gilles Savard. 2007. "An Overview of Bilevel Optimization." Annals of Operations Research 153 (1): 235-56. doi:10.1007/s10479007-0176-2.

De Benedetto, Luca, and Jiří Klemeš. 2009. "The Environmental Performance Strategy Map: An Integrated LCA Approach to Support the Strategic Decision-Making Process." Journal of Cleaner Production 17 (10): 900-906. doi:10.1016/j.jclepro.2009.02.012.

Dempe, Stephan. 2002. Foundations of Bilevel Programming. Springer.

Devanathan, Srikanth, Devarajan Ramanujan, William Z. Bernstein, Fu Zhao, and Karthik Ramani. 2010. "Integration of Sustainability Into Early Design Through the Function Impact Matrix." Journal of Mechanical Design 132 (8): 081004. doi:10.1115/1.4001890.

Doran, D. 2003. "Supply Chain Implications of Modularization." International Journal of Operations and Productions Management 23 (3): 316-26.

Dowlatshahi, S. 1992. "Purchasing's Role in a Concurrent Engineering Environment." International Journal of Purchasing and Materials Management 28 (1): 21-25.

Duflou, Joost R., John W. Sutherland, David Dornfeld, Christoph Herrmann, Jack Jeswiet, Sami Kara, Michael Hauschild, and Karel Kellens. 2012. "Towards Energy and Resource Efficient Manufacturing: A Processes and Systems Approach." CIRP Annals Manufacturing Technology 61 (2): 587-609. doi:10.1016/j.cirp.2012.05.002.

Eastlick, D.D., M.V. Sahakian, and K.R. Haapala. 2011. "Sustainable Manufacturing Analysis for Titanium Components." In Design for Manufacturing and the Lifecycle Conference (DFMLC). Washington, D.C.: Paper DETC2011-48854, 2011 ASME/DETC Design for Manufacturing and the Lifecycle Conference (DFMLC).

ElMaraghy, H. A., and N. Mahmoudi. 2009. "Concurrent Design of Product Modules Structure and Global Supply Chain Configurations.” International Journal of Computer Integrated Manufacturing 22 (6): 483-93. doi:10.1080/09511920802389553.

Eyring, Gregory. 1992. Green Products by Design: Choices for a Cleaner Environment. DIANE Publishing.

Fabricius, Finn. 1994. "A Seven Step Procedure for Design for Manufacture." World Class Design to Manufacture 1 (2): 23-30. doi:10.1108/09642369210054243.

Fang, Kan, Nelson Uhan, Fu Zhao, and John W. Sutherland. 2011. "A New Approach to Scheduling in Manufacturing for Power Consumption and Carbon Footprint Reduction." Journal of Manufacturing Systems 30 (4): 234-40. doi:10.1016/j.jmsy.2011.08.004.

Feng, Shaw C., and Che B. Joung. 2011. "A Measurement Infrastructure for Sustainable Manufacturing." International Journal of Sustainable Manufacturing 2 (2): 204-21. doi:10.1504/IJSM.2011.042152.

Ferrer, Geraldo. 2001. "On the Widget Remanufacturing Operation." European Journal of Operational Research 135 (2). Financial Modelling: 373-93. doi:10.1016/S03772217(00)00318-0. 
Ferrer, I, J Rios, and J Ciurana. 2009. "An Approach to Integrate Manufacturing Process Information in Part Design Phases." Journal of Materials Processing Technology 209 (4): 2085-91.

Fisher, M. 1997. "What Is Right Supply Chain for Your Product?" Harvard Business Review 75: $105-17$.

Fleischer, J., and J. Schaedel. 2013. "Joining Automotive Space Frame Structures by Filament Winding." CIRP Journal of Manufacturing Science and Technology 6 (2): 98-101. doi:10.1016/j.cirpj.2013.02.003.

Frota Neto, J. Quariguasi, J. M. Bloemhof-Ruwaard, J. A. E. E. van Nunen, and E. van Heck. 2008. "Designing and Evaluating Sustainable Logistics Networks." International Journal of Production Economics 111 (2). Special Section on Sustainable Supply Chain: 195-208. doi:10.1016/j.ijpe.2006.10.014.

Gan, Thiam-Soon, and Martin Grunow. 2013. "Concurrent Product - Supply Chain Design: A Conceptual Framework \& Literature Review." Procedia CIRP 7. Forty Sixth CIRP Conference on Manufacturing Systems 2013: 91-96. doi:10.1016/j.procir.2013.05.016.

Gehin, A., P. Zwolinski, and D. Brissaud. 2008. "A Tool to Implement Sustainable End-of-Life Strategies in the Product Development Phase." Journal of Cleaner Production 16 (5): 566-76. doi:10.1016/j.jclepro.2007.02.012.

GHG: Greenhouse Gas Reporting Program, 2011. http://www.epa.gov/ghgreporting/ ghgdata/reported-2011/index.html

Gold, Stefan, Stefan Seuring, and Philip Beske. 2010. "Sustainable Supply Chain Management and Inter-Organizational Resources: A Literature Review." Corporate Social Responsibility and Environmental Management 17 (4): 230-45. doi:10.1002/csr.207.

Graedel, T. E, and B. R Allenby. 2002. "Hierarchical Metrics for Sustainability." Environmental Quality Management 12 (2): 21-30. doi:10.1002/tqem.10060.

Green Power Network (GPN) 2014. http://apps3.eere.energy.gov/greenpower/.

Guide Jr., V. Daniel R. 2000. "Production Planning and Control for Remanufacturing: Industry Practice and Research Needs." Journal of Operations Management 18 (4): 467-83. doi:10.1016/S0272-6963(00)00034-6.

Guillén-Gosálbez, Gonzalo, and Ignacio E. Grossmann. 2009. "Optimal Design and Planning of Sustainable Chemical Supply Chains under Uncertainty.” AIChE Journal 55 (1): 99-121. doi:10.1002/aic.11662.

Gümüş, Zeynep H., and Christodoulos A. Floudas. 2005. "Global Optimization of Mixed-Integer Bilevel Programming Problems." Computational Management Science 2 (3): 181-212. doi:10.1007/s10287-005-0025-1.

Gupta, Saraj, and Gül E. Okudan. 2008. "Computer-Aided Generation of Modularised Conceptual Designs with Assembly and Variety Considerations." Journal of Engineering Design 19 (6): 533-51. doi:10.1080/09544820802527106.

Gutowski, Timothy, Cynthia Murphy, David Allen, Diana Bauer, Bert Bras, Thomas Piwonka, Paul Sheng, John Sutherland, Deborah Thurston, and Egon Wolff. 2005. "Environmentally Benign Manufacturing: Observations from Japan, Europe and the United States." Journal of Cleaner Production 13 (1): 1-17. doi:16/j.jclepro.2003.10.004.

Haapala, Karl R., Fu Zhao, Jaime Camelio, John W. Sutherland, Steven J. Skerlos, David A. Dornfeld, I. S. Jawahir, Andres F. Clarens, and Jeremy L. Rickli. 2013. "A Review of Engineering Research in Sustainable Manufacturing." Journal of Manufacturing Science and Engineering 135 (4): 041013-1 - 041013-16. doi:10.1115/1.4024040. 
Harjula, T., B. Rapoza, W. A. Knight, and G. Boothroyd. 1996. "Design for Disassembly and the Environment." CIRP Annals - Manufacturing Technology 45 (1): 109-14. doi:10.1016/S0007-8506(07)63027-3.

Haynsworth, H.C., and R.T. Lyons. 1987. "Emanufacturing by Design, the Missing Link." Production and Inventory Management 28 (2): 14-29.

He, Y, B Liu, X Zhang, H Gao, and X Liu. 2012. "A Modeling Method of Task-Oriented Energy Consumption for Machining Manufacturing System." Journal of Cleaner Production 23 (1): $167-74$.

Hernandez-Matias, J. C., A. Vizan, A. Hidalgo, and J. Rios. 2006. "Evaluation of Techniques for Manufacturing Process Analysis." Journal of Intelligent Manufacturing 17 (5): 571-83. doi:10.1007/s10845-006-0025-1.

Herrmann, I.T., and M.Z. Hauschild. 2009. "Effects of Globalisation on Carbon Footprints of Products." CIRP Annals - Manufacturing Technology 58: 13-16. doi:10.1016/j.cirp.2009.03.078.

Hertwich, Edgar G., and Glen P. Peters. 2009. "Carbon Footprint of Nations: A Global, TradeLinked Analysis." Environmental Science \& Technology 43 (16): 6414-20. doi:10.1021/es803496a.

Hoen, K. M. R., Tarkan Tan, J. C. Fransoo, and G. J. Van Houtum. 2010. "Effect of Carbon Emission Regulations on Transport Mode Selection in Supply Chains." Eindhoven University of Technology.

Howarth, George, and Mark Hadfield. 2006. "A Sustainable Product Design Model." Materials \& Design 27 (10): 1128-33. doi:10.1016/j.matdes.2005.03.016.

Hugo, A., and E. N. Pistikopoulos. 2005. "Environmentally Conscious Long-Range Planning and Design of Supply Chain Networks." Journal of Cleaner Production 13 (15). Recent Advances in Industrial Process Optimisation Recent Advances in Industrial Process Optimisation: 1471-91. doi:10.1016/j.jclepro.2005.04.011.

Hutchins, Margot J., and John W. Sutherland. 2008. "An Exploration of Measures of Social Sustainability and Their Application to Supply Chain Decisions." Journal of Cleaner Production 16 (15): 1688-98. doi:16/j.jclepro.2008.06.001.

Ibbotson, Suphunnika, and Sami Kara. 2011. "Carbon Footprint Anaysis of Products Cradle-toGate and Manufacturing Supply Chains." In Proceedings of the 7th Australian Conference on Life Cycle Assessment, 1-10. East Melbourne, Australia: Australian Life Cycle Assessment Society Inc.

Ijomah, W. L., C. A. McMahon, G. P. Hammond, and S. T. Newman. 2007a. "Development of Robust Design-for-Remanufacturing Guidelines to Further the Aims of Sustainable Development." International Journal of Production Research 45 (18-19): 4513-36. doi:10.1080/00207540701450138.

Ijomah, Winifred L., Christopher A. McMahon, Geoffrey P. Hammond, and Stephen T. Newman. 2007b. "Development of Design for Remanufacturing Guidelines to Support Sustainable Manufacturing." Robotics and Computer-Integrated Manufacturing 23 (6). 16th International Conference on Flexible Automation and Intelligent Manufacturing: 712-19. doi:10.1016/j.rcim.2007.02.017.

Ilgin, Mehmet Ali, and Surendra M. Gupta. 2010. "Environmentally Conscious Manufacturing and Product Recovery (ECMPRO): A Review of the State of the Art." Journal of Environmental Management 91 (3): 563-91. doi:16/j.jenvman.2009.09.037. 
Ishii, K., and B. Lee. 1996. "Reverse Fishbone Diagram: A Tool in Aid of Design for Product Retirement." In Proceedings of the ASME Design Technical Conference, Paper 96DETC/DFM-1272. Irvine, California: ASME.

Jeswiet, J, and P Nava. 2009. "Applying CES to Assembly and Comparing Carbon Footprints." International Journal of Sustainable Engineering 2 (4): 232-40.

Joyce, Toby, Thomas A. Okrasinski, and William Schaeffer. 2010. "Estimating the Carbon Footprint of Telecommunications Products: A Heuristic Approach." Journal of Mechanical Design 132 (9): 094502. doi:10.1115/1.4002143.

Kellens, K., W. Dewulf, M. Overcash, M. Hauschild, and J. Duflou. 2012a. "Methodology for Systematic Analysis and Improvement of Manufacturing Unit Process Life Cycle Inventory (uplci) CO2PE! Initiative (Cooperative Effort on Process Emissions in Manufacturing), Part 2: Case Studies." The International Journal of Life Cycle Assessment 17 (2): 242-51. doi:10.1007/s11367-011-0352-0.

Kellens, K., W. Dewulf, M. Overcash, M. Z. Hauschild, and J. R. Duflou. 2012b. "Methodology for Systematic Analysis and Improvement of Manufacturing Unit Process Life-Cycle Inventory (uplci) - CO2PE! Initiative (Cooperative Effort on Process Emissions in Manufacturing), Part 1: Methodology Description.” The International Journal of Life Cycle Assessment 17 (1): 69-78. doi:10.1007/s11367-011-0340-4.

Khalaf, Radwan El Hadj, Bruno Agard, and Bernard Penz. 2008. "Product and Supply Chain Design Using a Two-Phases Optimisation Approach." In Proceedings of the International Conference on Information Systems, Logistics and Supply Chain (ILS).

Khalaf, Radwan El Hadj, Bernard Penz, and Bruno Agard. 2009. An Optimization Method for the Simultaneous Design of a Product Family and Its Related Supply Chain Using a Taboo Search Algorithm. CIRRELT.

Kim, Hyung-Ju, Gregory A. Keoleian, and Steven J. Skerlos. 2011. "Economic Assessment of Greenhouse Gas Emissions Reduction by Vehicle Lightweighting Using Aluminum and High-Strength Steel." Journal of Industrial Ecology 15 (1): 64-80. doi:10.1111/j.15309290.2010.00288.x.

Kim, K.-Y., K.-C. Lee, and O. Kwon. 2008c. "The Role of the Fuzzy Cognitive Map in Hierarchical Semantic Net-Based Assembly Design Decision Making." International Journal of Computer Integrated Manufacturing 21 (7): 803-24. doi:10.1080/09511920701756969.

Kim, Kyoung-Yun, Seongah Chin, Ohbyung Kwon, and R. Darin Ellis. 2009. "Ontology-Based Modeling and Integration of Morphological Characteristics of Assembly Joints for Network-Based Collaborative Assembly Design.” AI EDAM 23 (Special Issue 01): 71-88. doi:10.1017/S0890060409000110.

Kim, Kyoung-Yun, Keunho Choi, and Ohbyung Kwon. 2008a. "Rule Selection for Collaborative Ubiquitous Smart Device Development: Rough Set Based Approach." In Ubiquitous Intelligence and Computing, edited by Frode Eika Sandnes, Yan Zhang, Chunming Rong, Laurence T. Yang, and Jianhua Ma, 386-96. Lecture Notes in Computer Science 5061. Springer Berlin Heidelberg. http://link.springer.com/chapter/10.1007/978-3-540-692935_31.

Kim, Kyoung-Yun, Yan Wang, Obinna S. Muogboh, and Bartholomew O. Nnaji. 2004. "Design Formalism for Collaborative Assembly Design." Computer-Aided Design 36 (9). Distributed CAD for Supporting Internet Collaborative Design: 849-71. doi:10.1016/j.cad.2003.09.011. 
Kim, Kyoung-Yun, Hyungjeong Yang, and Dong-Won Kim. 2008b. "Mereotopological Assembly Joint Information Representation for Collaborative Product Design." Robotics and Computer-Integrated Manufacturing 24 (6). FAIM 2007 17th International Conference on Flexible Automation and Intelligent Manufacturing: 744-54. doi:10.1016/j.rcim.2008.03.010.

Komoto, H, T Tomiyama, S Silvester, and H Brezet. 2009. "Analyzing Supply Chain Robustness for OEMs From a Life Cycle Perspective Using Life Cycle Simulation.” International Journal of Production Economics 134 (2): 447-57.

Kremer, Gül E. Okudan, and Saraj Gupta. 2013. "Analysis of Modularity Implementation Methods from an Assembly and Variety Viewpoints." The International Journal of Advanced Manufacturing Technology 66 (9-12): 1959-76. doi:10.1007/s00170-0124473-9.

Krikke, H., J. Bloemhof-Ruwaard, and L. N. Van Wassenhove. 2003. "Concurrent Product and Closed-Loop Supply Chain Design with an Application to Refrigerators." International Journal of Production Research $41 \quad$ (16): $3689-3719$. doi:10.1080/0020754031000120087.

Krishnan, V., and Karl T. Ulrich. 2001. "Product Development Decisions: A Review of the Literature." Management Science 47 (1): 1-21. doi:10.1287/mnsc.47.1.1.10668.

Kwak, M.J., Y.S. Hong, and N.W. Cho. 2009. "Eco-Architecture Analysis for End-of-Life Decision Making." International Journal of Production Research 47 (22): 6233-59.

Lambert, Douglas M, and Martha C Cooper. 2000. "Issues in Supply Chain Management." Industrial Marketing Management 29 (1): 65-83. doi:10.1016/S0019-8501(99)00113-3.

Lamothe, Jacques, Khaled Hadj-Hamou, and Michel Aldanondo. 2006. "An Optimization Model for Selecting a Product Family and Designing Its Supply Chain.” European Journal of Operational Research 169 (3): 1030-47. doi:10.1016/j.ejor.2005.02.007.

Laurent, A., S.I. Olsen, and M.Z. Hauschild. 2010. "Carbon Footprint as Environmental Performance Indicator for the Manufacturing Industry.” CIRP Annals - Manufacturing Technology 59 (1): 37-40. doi:10.1016/j.cirp.2010.03.008.

Lee, Hau L., and Marguerita M. Sasser. 1995. "Product Universality and Design for Supply Chain Management." Production Planning \& Control 6 (3): 270-77. doi:10.1080/09537289508930279.

Lee, K.H. 2012. "Carbon Accounting for Supply Chain Management in the Automobile Industry." Journal of Cleaner Production 36: 83-93.

Lei, T. 2013. "GIS-Based Hierarchical Multi-Objective Supply Chain Design: A Proposed Tool \& Case Study". The Pennsylvania State University.

Lei, T. and Okudan Kremer, G.E. "GIS-Based Hierarchical Multi-Objective Supply Chain Network Design: A Proposed Tool \& Case Study”, Industrial and Systems Engineering Conference (ISERC 2013), May 18-22, San Juan, Puerto Rico.

Lin, Xiannuan, and Karen R. Polenske. 1998. "Input — output Modeling of Production Processes for Business Management." Structural Change and Economic Dynamics 9 (2): 205-26. doi:10.1016/S0954-349X(97)00034-9.

Ljungberg, Lennart Y. 2007. "Materials Selection and Design for Development of Sustainable Products." Materials \& Design 28 (2): 466-79. doi:10.1016/j.matdes.2005.09.006.

Lu, T., A. Gupta, A. D. Jayal, F. Badurdeen, S. C. Feng, O. W. Dillon, and I. S. Jawahir. 2010. "A Framework of Product and Process Metrics for Sustainable Manufacturing." In 
Proceedings of the Eighth International Conference on Sustainable Manufacturing. Abu Dhabi, UAE, November 22-24.

Mangun, D., and D.J. Thurston. 2002. "Incorporating Component Reuse, Remanufacture, and Recycle into Product Portfolio Design.” IEEE Transactions on Engineering Management 49 (4): 479-90. doi:10.1109/TEM.2002.807292.

Mani, M., J. Madan, J.H. Lee, K.W. Lyons, and S.K. Gupta. "Sustainability Characterisation for Manufacturing Processes." International Journal of Production Research, February 28, 2014, 1-18. doi:10.1080/00207543.2014.886788.

Matthews, H. Scott, Chris T. Hendrickson, and Christopher L. Weber. 2008. "The Importance of Carbon Footprint Estimation Boundaries." Environmental Science \& Technology 42 (16): 5839-42. doi:10.1021/es703112w.

Mihelcic, James R., John C. Crittenden, Mitchell J. Small, David R. Shonnard, David R. Hokanson, Qiong Zhang, Hui Chen, et al. 2003. "Sustainability Science and Engineering: The Emergence of a New Metadiscipline." Environmental Science \& Technology 37 (23): 5314-24. doi:10.1021/es034605h.

Miller, Geoff, Janice Pawloski, and Charles Robert Standridge. 2010. "A Case Study of Lean, Sustainable Manufacturing." Journal of Industrial Engineering and Management 3 (1). doi:10.3926/jiem.2010.v3n1.p11-32.

Mikkola, Juliana, and Skjøtt-Larsen, Tage. 2004. "Supply-Chain Integration: Implications for Mass Customization, Modularization and Postponement Strategies." Production Planning \& Control 15 (4): 352-61. doi:10.1080/0953728042000238845. http://www.jiem.org/index.php/jiem/article/view/156.

Nasr, Nabil, and Brian Hilton. 2008. "Design for Remanufacturing." In 15th CIRP International Conference on Life Cycle Engineering. http://search.informit.com.au/documentSummary;dn=560734358067302;res=IELENG.

National Research Council (U.S.). 1995. Unit Manufacturing Processes: Issues and Opportunities in Research. Washington, D.C: National Academy Press. http://www.nap.edu/catalog.php?record_id=4827.

Navin-Chandra, D. 1993. "ReStar: A Design Tool for Environmental Recovery Analysis." In 9th International Conference on Engineering Design, 780-87. Heurista, Zurich.

Nepal, Bimal, Leslie Monplaisir, and Oluwafemi Famuyiwa. 2011. "A Multi-Objective Supply Chain Configuration Model for New Products." International Journal of Production Research 49 (23): 7107-34. doi:10.1080/00207543.2010.511294.

Newcomb, P. J., B. Bras, and D. W. Rosen. 1998. "Implications of Modularity on Product Design for the Life Cycle." Journal of Mechanical Design 120 (3): 483-90. doi:10.1115/1.2829177.

Niinimäki, K, and L Hassi. 2011. "Emerging Design Strategies in Sustainable Production and Consumption of Textiles and Clothing." Journal of Cleaner Production 19 (16): 1876-83.

Nissen, Ulrich. 1995. "A Methodology for the Development of Cleaner Products: The Ideal-EcoProduct Approach." Journal of Cleaner Production 3 (1-2). European Roundtable on Cleaner Production Programs: 83-87. doi:10.1016/0959-6526(95)98166-L.

OECD. 2008. "OECD: Key Environmental Indicators". Paris, France: OECD Environment Directorate. outlooks/37551205.pdf.

http://www.oecd.org/environment/indicators-modelling-

Ogot, Madara, and Gul Okudan-Kremer. 2004. Engineering Design: A Practical Guide. Trafford Publishing. 
Okudan, G.E., T.K. Lin, and M.C. Chiu. 2012. "Carbon Footprint Implications of Modularity and Projections for the Reverse Logistics.” In International Workshop on Green Supply Chain. Arras, France.

Olson, E.C. 2010. "Integration Between Product Design And Supply Chain With Consideration For Sustainability". The Pennsylvania State University.

Olson, Elizabeth, Karl R. Haapala, and Gül E. Okudan. 2011. "Integration of Sustainability Issues during Early Design Stages in a Global Supply Chain Context." In Artificial Intelligence and Sustainable Design. Stanford, California, USA.

Overcash, Michael, Janet Twomey, and Devi Kalla. 2009. "Unit Process Life Cycle Inventory for Product Manufacturing Operations." In ASME Conference Proceedings, 1:49-55. West Lafayette, Indiana, USA: ASME. doi:10.1115/MSEC2009-84065. http://link.aip.org/link/abstract/ASMECP/v2009/i43611/p49/s1.

Pan, Shenle, Eric Ballot, and Frédéric Fontane. 2013. "The Reduction of Greenhouse Gas Emissions from Freight Transport by Pooling Supply Chains." International Journal of Production Economics 143 (1): 86-94. doi:10.1016/j.ijpe.2010.10.023.

Pham, D. T., P. T. N. Pham, and A. Thomas. 2008. "Integrated Production Machines and Systems - beyond Lean Manufacturing." Journal of Manufacturing Technology Management 19 (6): 695-711. doi:10.1108/17410380810888094.

Philip, N. 2012. "An Investigation on the Supply Chain Implications of Modularized Designs Considering End-of-Life Options and Life Expectancy". Master's Thesis, State College, Pennsylvania: Department of Industrial and Manufacturing Engineering, Pennsylvania State University.

Philip, N., G.E. Okudan, K.R. Haapala, and K.Y. Kim. 2013. "Comparison of Modularity Methods for Their Implications on Sustainability." In Industrial and Systems Engineering Conference. San Juan, Puerto Rico.

Philip, N., Gül E. Okudan, K. R. Haapala, and Kyoung-Yun Kim. 2012. "Computer-Aided Generation of Modular Designs Considering Component End-of-Life Options: Implications for the Supply Chain." In Proceedings of the 2012 ASME IDETC/CIE: 17th Design for Manufacturing and the Lifecycle Conference (DFMLC), Paper DETC201271180. Chicago, IL, USA.

Pusavec, Franci, Peter Krajnik, and Janez Kopac. 2010. "Transitioning to Sustainable Production - Part I: Application on Machining Technologies.” Journal of Cleaner Production 18 (2): 174-84. doi:10.1016/j.jclepro.2009.08.010.

Rajemi, M.F., P.T. Mativenga, and A. Aramcharoen. 2010. "Sustainable Machining: Selection of Optimum Turning Conditions Based on Minimum Energy Considerations." Journal of Cleaner Production 18 (10-11): 1059-65. doi:10.1016/j.jclepro.2010.01.025.

Ramani, Karthik, Devarajan Ramanujan, William Z. Bernstein, Fu Zhao, John Sutherland, Carol Handwerker, Jun-Ki Choi, Harrison Kim, and Deborah Thurston. 2010. "Integrated Sustainable Life Cycle Design: A Review." Journal of Mechanical Design 132 (9): 091004-15. doi:10.1115/1.4002308.

Ramudhin, A., A. Chaabane, and M. Paquet. 2009. "On the Design of Ustainable, Green Supply Chains." In International Conference on Computers Industrial Engineering, 2009. CIE 2009, 979-84. doi:10.1109/ICCIE.2009.5223686.

Ramudhin, Amar, Amin Chaabane, and Marc Paquet. 2008. "Carbon Market Sensitive Green Supply Chain Network Design." In IEEE International Conference on Industrial Engineering and Engineering Management, 1093-97. 
Reap, John, Felipe Román, Tina Guldberg, and Bert Bras. 2006. "Integrated Ecosystem Landscape and Industrial Modeling for Strategic Environmentally Conscious Process Technology Selection Abstract." In 13th CIRP International Conference on Life Cycle Engineering, 213-18. Leuven, Belgium. http://citeseerx.ist.psu.edu/viewdoc/summary?doi=10.1.1.87.103.

Reuter, Carsten, Kai Foerstl, Evi Hartmann, and Constantin Blome. 2010. "Sustainable Global Supplier Management: The Role of Dynamic Capabilities in Achieving Competitive Advantage." Journal of Supply Chain Management 46 (2): 45-63. doi:10.1111/j.1745493X.2010.03189.x.

Rose, C.M., A. Stevels, and K. Ishii. 2000. "A New Approach to End-of-Life Design Advisor (ELDA)." In Proceedings of the 2000 IEEE International Symposium on Electronics and the Environment, 99-104. San Francisco, CA: IEEE. doi:10.1109/ISEE.2000.857632. http://ieeexplore.ieee.org/lpdocs/epic03/wrapper.htm?arnumber=857632.

Sarkis, Joseph, Qinghua Zhu, and Kee-hung Lai. 2011. "An Organizational Theoretic Review of Green Supply Chain Management Literature." International Journal of Production Economics 130 (1): 1-15. doi:10.1016/j.ijpe.2010.11.010.

Seuring, Stefan, and Martin Müller. 2008. "From a Literature Review to a Conceptual Framework for Sustainable Supply Chain Management." Journal of Cleaner Production 16 (15): 1699-1710. doi:16/j.jclepro.2008.04.020.

Sheng, Paul, and Paul Worhach. 1997. "A Process Chaining Approach toward Product Design for Environment." Journal of Industrial Ecology 1 (4): 35-55. doi:10.1162/jiec.1997.1.4.35.

Sherwood, M., L. H. Shu, and R. G. Fenton. 2000. "Supporting Design for Remanufacture through Waste-Stream Analysis of Automotive Remanufacturers." CIRP Annals Manufacturing Technology 49 (1): 87-90. doi:10.1016/S0007-8506(07)62902-3.

Short, T. D., and C. A. Lynch. 2004. "Beyond the Eco-Functional Matrix-Design for Sustainability and the Durham Methodology." In Proceeding of Design and Manufacture for Sustainable Development Conference 2004, 175-84.

Shu, L.H., and W.C. Flowers. 1995. "Considering Remanufacture and Other End-of-Life Options in Selection of Fastening and Joining Methods." In , Proceedings of the 1995 IEEE International Symposium on Electronics and the Environment, 1995. ISEE, 75-80. doi:10.1109/ISEE.1995.514953.

Shuaib, M., H. Metta, T. Lu, F. Badurdeen, I. S. Jawahir, and T. Goldsby. 2011. "Design and Performance Evaluation of Sustainable Supply Chains: Approach and Methodologies." In Advances in Sustainable Manufacturing, 347-52. Berlin, Heidelberg: Springer Berlin Heidelberg. http://www.springerlink.com/content/x480x16651036071/.

Sourirajan, K., P. Centonze, M.E. Helander, K. Katircioglu, M. Ben-Hamida, and C. Boucher. 2009. "Carbon Management in Assembly Manufacturing Logistics." IBM Journal of Research and Development 53 (3): 8:1-8:16. doi:10.1147/JRD.2009.5429021.

Spangenberg, J.H., A Fuad-Luke, and K Blincoe. 2010. "Design for Sustainability (DfS): The Interface of Sustainable Production and Consumption." Journal of Cleaner Production 18 (15): 1485-93.

Stoll, Henry W. 1988. "Design for Manufacture."Manufacturing Engineering 100(1), January 1988, 67- 73. 
Subramanian, Ravi, Brian Talbot, and Sudheer Gupta. 2010. "An Approach to Integrating Environmental Considerations Within Managerial Decision-Making." Journal of Industrial Ecology 14 (3): 378-98. doi:10.1111/j.1530-9290.2010.00243.x.

Sundin, E. 2001. "Enhanced Product Design Facilitating Remanufacturing of Two Household Appliances: A Case Study." In WDK Publications, 645-52. http://cat.inist.fr/?aModele=afficheN\&cpsidt $=15347853$.

Sundin, Erik, and Bert Bras. 2005. "Making Functional Sales Environmentally and Economically Beneficial through Product Remanufacturing." Journal of Cleaner Production 13 (9): 913-25. doi:10.1016/j.jclepro.2004.04.006.

Supply Chain Council (SCC). 2014. "Supply-Chain.Org: FAQ." Supply-Chain.Org: FAQ. https://archive.supply-chain.org/cs/root/about_us/faq.

Sutherland, J.W., and K.L. Gunter. 2001. "Chapter 13. Environmental Attributes of Manufacturing Processes." In Handbook of Environmentally Conscious Manufacturing, edited by C.N. Madu, 1st ed., 293-316. Kluwer Academic Publishers.

Taghavi, Ali, and Ratna Babu Chinnam. 2014. "Assortment Planning of Automotive Products with Considerations for Economic and Environmental Impacts of Technology Selection." Journal of Cleaner Production. doi:10.1016/j.jclepro.2014.02.004. http://www.sciencedirect.com/science/article/pii/S0959652614001450.

Taghavi Behbahani, Seyed Ali. 2012. "An Integrated Framework For Configurable Product Assortment Planning." Wayne State University Dissertations, January. http://digitalcommons.wayne.edu/oa_dissertations/706.

Thonemann, Ulrich W., and James R. Bradley. 2002. "The Effect of Product Variety on SupplyChain Performance." European Journal of Operational Research 143 (3): 548-69. doi:10.1016/S0377-2217(01)00343-5.

Ülkü, Sezer, and Glen M. Schmidt. 2011. "Matching Product Architecture and Supply Chain Configuration." Production and Operations Management 20 (1): 16-31. doi:10.1111/j.1937-5956.2010.01136.x.

Ulrich, Karl, and Karen Tung. 1991. "Fundamentals of Product Modularity." In Proceedings of the 1991 ASME Winter Annual Meeting Symposium on Issues in Design/Manufacture Integration, 39:73-79. Atlanta, Georgia: ASME.

Umeda, Yasushi, Shozo Takata, Fumihiko Kimura, Tetsuo Tomiyama, John W. Sutherland, Sami Kara, Christoph Herrmann, and Joost R. Duflou. 2012. "Toward Integrated Product and Process Life Cycle Planning-an Environmental Perspective." CIRP Annals Manufacturing Technology 61 (2): 681-702. doi:10.1016/j.cirp.2012.05.004.

Umpfenbach, Edward. 2013. "Optimization Of Strategic Planning Processes For Configurable Products: Considerations For Global Supply, Demand, And Sustainability Issues." Wayne State University Dissertations, January. http://digitalcommons.wayne.edu/oa_dissertations/710.

Vinodh, S, and G Rathod. 2010. "Integration of ECQFD and LCA for Sustainable Product Design.” Journal of Cleaner Production 18 (8): 833-42.

Vonderembse, Mark A., Mohit Uppal, Samuel H. Huang, and John P. Dismukes. 2006. "Designing Supply Chains: Towards Theory Development." International Journal of Production Economics 100 (2): 223-38. doi:10.1016/j.ijpe.2004.11.014.

Waage, Sissel A. 2007. "Re-Considering Product Design: A Practical 'road-Map' for Integration of Sustainability Issues." Journal of Cleaner Production 15 (7): 638-49. doi:10.1016/j.jclepro.2005.11.026. 
Warnecke, H. J., and R. Bäßler. 1988. "Design for Assembly — Part of the Design Process." CIRP Annals - Manufacturing Technology 37 (1): 1-4. doi:10.1016/S00078506(07)61572-8.

Weber, Christopher L., and H. Scott Matthews. 2008. "Quantifying the Global and Distributional Aspects of American Household Carbon Footprint.” Ecological Economics 66 (June).

Williams, J., L. Shu, and T. Murayama. 2000. "Current Status of Extended Producer Responsibility Legislation and Effects on Product Design." In ASME Japan-USA Symposium on Flexible Automation. Ann Arbor, MI.

Yan, Hong, Zhenxin Yu, and T. C. Edwin Cheng. 2003. "A Strategic Model for Supply Chain Design with Logical Constraints: Formulation and Solution." Computers \& Operations Research 30 (14): 2135-55. doi:10.1016/S0305-0548(02)00127-2.

Yang, Biao, N.D. Burns, and C.J. Backhouse. 2005. "The Application of Postponement in Industry." IEEE Transactions on Engineering Management 52 (2): 238-48. doi:10.1109/TEM.2005.845223.

Youn, Sunhee, Ma Ga (Mark) Yang, Paul Hong, and Kihyun Park. 2013. "Strategic Supply Chain Partnership, Environmental Supply Chain Management Practices, and Performance Outcomes: An Empirical Study of Korean Firms." Journal of Cleaner Production 56 (October): 121-30. doi:10.1016/j.jclepro.2011.09.026.

Zhu, Qinghua, Yijie Dou, and Joseph Sarkis. 2010. "A Portfolio-Based Analysis for Green Supplier Management Using the Analytical Network Process." Supply Chain Management: An International Journal 15 (4): 306-19. doi:10.1108/13598541011054670.

Zsidisin, George A, and Sue P Siferd. 2001. "Environmental Purchasing: A Framework for Theory Development." European Journal of Purchasing \& Supply Management 7 (1): 61-73. doi:10.1016/S0969-7012(00)00007-1.

Zwolinski, Peggy, Miguel-Angel Lopez-Ontiveros, and Daniel Brissaud. 2006. "Integrated Design of Remanufacturable Products Based on Product Profiles." Journal of Cleaner Production 14 (15-16). EcoDesign: What's Happening? 1333-45. doi:10.1016/j.jclepro.2005.11.028. 


\section{Appendix}

Table A1. Component Supplier Information(Bicycle.net 2010)

\begin{tabular}{|c|c|c|c|c|c|}
\hline Supplier & Unit cost & $\begin{array}{c}\text { Unit } \\
\text { order cost }\end{array}$ & $\begin{array}{c}\text { Avg. } \\
\text { defect ratio }\end{array}$ & $\begin{array}{l}\text { Avg. } \\
\text { delivery } \\
\text { delay }\end{array}$ & $\begin{array}{l}\text { Supply } \\
\text { quantity }\end{array}$ \\
\hline \multicolumn{6}{|l|}{ [A] Saddle } \\
\hline Vello & 5.25 & 0.021 & 0.1 & 8 & 10000 \\
\hline Viscount & 6.02 & 0.021 & 0.03 & 14 & 5000 \\
\hline \multicolumn{6}{|l|}{ [B] Frame } \\
\hline X-bike & 318 & 0.013 & 0.01 & 7 & 15000 \\
\hline ADK & 276 & 0.014 & 0.15 & 13 & 1000 \\
\hline Topkey & 243.8 & 0.007 & 0.12 & 6 & 8000 \\
\hline \multicolumn{6}{|l|}{ [C] Fork } \\
\hline X-bike & 113 & 0.018 & 0.14 & 7 & 4000 \\
\hline ADK & 60 & 0.022 & 0.05 & 4 & 9000 \\
\hline Advanced & 29.12 & 0.019 & 0.1 & 2 & 4000 \\
\hline Easton Sports & 87.35 & 0.011 & 0.03 & 12 & 2000 \\
\hline Topkey & 79 & 0.021 & 0.11 & 10 & 5000 \\
\hline \multicolumn{6}{|l|}{ [D] Brake } \\
\hline X-bike & 81.25 & 0.028 & 0.06 & 13 & 1000 \\
\hline SRAM & 31.66 & 0.022 & 0.03 & 13 & 8000 \\
\hline Tektro & 21 & 0.005 & 0.04 & 14 & 3000 \\
\hline Shimano & 7.54 & 0.014 & 0.11 & 13 & 2000 \\
\hline \multicolumn{6}{|l|}{ [E] Wheel } \\
\hline Spinner & 31.26 & 0.003 & 0.09 & 5 & 12000 \\
\hline Formula Engin & 14.32 & 0.018 & 0.08 & 11 & 800 \\
\hline \multicolumn{6}{|c|}{ [F] Transmission } \\
\hline SRAM & 147.54 & 0.021 & 0.13 & 4 & 8000 \\
\hline Tien Hsin & 32 & 0.004 & 0.12 & 4 & 10000 \\
\hline Shimano & 36.21 & 0.005 & 0.05 & 2 & 1000 \\
\hline
\end{tabular}


Table A2. Module Supplier Information(Bicycle.net 2010)

\begin{tabular}{|c|c|c|c|c|c|}
\hline Supplier & Unit cost & $\begin{array}{c}\text { Unit } \\
\text { order cost }\end{array}$ & $\begin{array}{c}\text { Avg. } \\
\text { defect ratio }\end{array}$ & $\begin{array}{l}\text { Avg. } \\
\text { delivery } \\
\text { delay }\end{array}$ & $\begin{array}{l}\text { Supply } \\
\text { quantity }\end{array}$ \\
\hline \multicolumn{6}{|l|}{ [AB] } \\
\hline ADK & 286 & 0.012 & 0.11 & 8 & 1500 \\
\hline Advanced & 299 & 0.008 & 0.09 & 5 & 1000 \\
\hline \multicolumn{6}{|l|}{ [CD] } \\
\hline SRAM & 132 & 0.015 & 0.12 & 14 & 2000 \\
\hline Tektro & 177 & 0.009 & 0.15 & 7 & 1100 \\
\hline \multicolumn{6}{|l|}{ [EF] } \\
\hline Shimano & 91 & 0.008 & 0.14 & 15 & 1550 \\
\hline \multicolumn{6}{|l|}{$[\mathrm{ABC}]$} \\
\hline X-bike & 326 & 0.023 & 0.16 & 17 & 1000 \\
\hline \multicolumn{6}{|l|}{ [DEF] } \\
\hline Spinner & 157 & 0.028 & 0.09 & 8 & 890 \\
\hline Formula Engin & 134 & 0.022 & 0.13 & 9 & 1005 \\
\hline \multicolumn{6}{|l|}{ [ABCDEF] } \\
\hline X-bike & 611 & 0.019 & 0.13 & 8 & 12000 \\
\hline Shimano & 519 & 0.014 & 0.09 & 5 & 770 \\
\hline
\end{tabular}


Table A3. Assembly CF in Kg CO2 Equivalent without Transportation(Philip et al. 2012)

\begin{tabular}{|c|c|c|c|c|c|c|c|c|}
\hline ID & Supplier & [A] & [B] & {$[\mathrm{C}]$} & [D] & {$[\mathrm{E}]$} & {$[\mathrm{F}]$} & Location \\
\hline 1 & X-bike & & 16.89 & 11.35 & 1.82 & & & USA \\
\hline 2 & ADK & & 15.52 & 4.12 & & & & USA \\
\hline 3 & Advanced & & & 4.12 & & & & USA \\
\hline 4 & $\begin{array}{l}\text { Easton } \\
\text { Sports }\end{array}$ & & & 4.12 & & & & USA \\
\hline 5 & SRAM & & & & 13.37 & & 6.70 & USA \\
\hline 6 & Vello & 0.64 & & 4.12 & & & & Taiwan \\
\hline 7 & Viscount & 0.60 & & & & & & $\begin{array}{l}\text { United } \\
\text { Kingdom }\end{array}$ \\
\hline 8 & Tektro & & & & 13.37 & & & Taiwan \\
\hline 9 & Topkey & & 15.52 & 11.35 & & & & Taiwan \\
\hline 10 & Tien Hsin & & & & & & 2.62 & Taiwan \\
\hline 11 & Shimano & & & & 13.21 & & 2.58 & Japan \\
\hline 12 & Spinner & & & & & 3.11 & & Taiwan \\
\hline 13 & $\begin{array}{l}\text { Formula } \\
\text { Engin }\end{array}$ & & & & & 15.54 & & Taiwan \\
\hline
\end{tabular}


Table A4. Carbon Footprint of Modules (Philip et al., 2012)

\begin{tabular}{ccc}
\hline Component A & Component B & Carbon Footprint (in $\mathrm{kg} \mathrm{CO}_{2}$ eq.) \\
\hline Saddle & Frame & 0.308 \\
Fork & Brake & 0.675 \\
Transmission & Wheel & 0.754 \\
Frame & Fork & 0.467 \\
Frame & Brake & 0.492 \\
Frame & Transmission & 0.523 \\
Frame & Wheel & 0.554 \\
Brake & Transmission & 0.308 \\
\hline
\end{tabular}

